\title{
Jean Rhys's Wide Sargasso Sea as a Hypertext of Charlotte Bronte's Jane Eyre: A Postmodern Perspective
}

\author{
Nazila Herischian \\ Department of English language and Literature, Tabriz Azad University \\ PO box 51575-5311, Tabriz, Iran \\ Tel: $00989144138938 \quad$ E-mail: nazila.herischian@yahoo.com
}

Received: 25-06- 2012

doi:10.7575/ijalel.v.1n.6p.72
Accepted: 03-08- 2012

Published: 01-11- 2012

\begin{abstract}
This study gains significance as the findings can shed more lights on the postmodern concept of hypertextuality to show that there is no originality in literature and any literary work can be the repetition, continuation, or mixture of previous texts. In the case of this study, that is to show, how a twentieth-century literary work like Rhys's Wide Sargasso Sea can be the parody of Brontë's nineteenth-century novel Jane Eyre. Moreover, such a postmodern perspective widens various ways of concentration on the literary works, so that, one could interpret in what ways two texts are united and grafted which results in either parody or pastiche. This study attempts to demonstrate mostly those focused aspects in Wide Sargasso Sea and Jane Eyre that highlight the concept of hypertextuality, including the analyses of Rochester's character in the novels, as a Byronic hero in Jane Eyre and an anti-Byronic hero in Wide Sargasso Sea; and also the study of the characters of Jane Eyre and Antoinette Cosway, as women narrator of the novels as well as focusing on the dream texts of the novels.
\end{abstract}

Key words: Hypertextuality, bildungsroman, Byronic hero, parody

\section{Introduction}

Charlotte Brontë, born in 1816, is one of the greatest novelists of Victorian era. Her novels have attracted attention of the critics as well as other novelists, especially towards her masterpiece Jane Eyre. She failed to focus on the real world around her because she paid more attention on the emotional life of her heroines. She read all she could find around her. She began writing poems and novels under the pseudonym of Currer Bell to hide her femininity. Charlotte finished Jane Eyre in 1847, which met with immediate success and she became an important literary figure.

Jean Rhys, born in Dominica, was a novelist who became famous only in the last decade of her life. As Emery states, "like other West Indian writers...Jean Rhys left the Caribbean island of her birth for the metropolitan centers of England and Europe... Rhys experienced a specifically female alienation and sexual vulnerability" (3). After her father's death she had to leave London's Academy of Dramatic Arts to earn her own living. She began writing in Paris in the 1920s, and then disappeared and her fiction went out of print. Rhys remained unnoticed until nearly the end of her life. It was after the publication of her last novel, Wide Sargasso Sea, that she was known as a West Indian writer. The novel is deeply influenced by Charlotte Brontë's Jane Eyre, in which Rhys said she decided to write about the mad woman imprisoned in the attic in Jane Eyre.

Charlotte Brontë and Jean Rhys composed their novels in different centuries and came from very different backgrounds. The famous Victorian novelist Charlotte Brontë, reflecting British culture has a great impact on Jean Rhys the West Indian novelist. Their novels, Jane Eyre and Wide Sargasso Sea, can be compared in many aspects that ranges from feminist, postcolonial, racist and symbolic trends to even contradictory readings of the novels, among which parodic trend is the focused feature of study in this research. In creating the character of Bertha Mason, Brontë unknowingly allowed for a whole other story and description of female experience to be told by Jean Rhys in Wide Sargasso Sea.

Jean Rhys's Wide Sargasso Sea can be considered as a response to Charlotte Brontë's Jane Eyre, in which Rhys makes use of Brontë's story as a basic source for her novel and rewrites an English text. In fact, the novels have been interwoven with some points of likeness as well as of differences. Thus, the confronted problem is that many aspects 
of Brontë's Jane Eyre have been repeated and some are parodied in Jean Rhys's Wide Sargasso Sea that make this novel a hypertext of Jane Eyre, a study of the former presupposes the study of the latter. According to Harrison "In responding to her reading of Brontë's text, Rhys sought not only to correct an omission, but also to correct what she considered a misreading of 'Creole women', part of whose identity was shaped by the British exploitative context" (128).

This paper attempts to demonstrate mostly those aspects in Wide Sargasso Sea and Jane Eyre that highlight the concept of hypertextuality, including the study of the characters of Jane Eyre and Antoinette Cosway, as women narrator of the novels, to trace the differences that make Brontë's Jane Eyre Bildungsroman in contrast with the antiBildungsroman elements of Rhys's Wide Sargasso Sea. And also the analyses of Rochester's character in the novels, as Byronic hero in Jane Eyre and a parodic anti-Byronic hero in Wide Sargasso Sea; as well as focusing on the dream texts of the novels.

This research also gains significance as the findings can shed more light on the postmodern concept of hypertextuality to show that there is no originality in literature and any literary work can be the repetition, continuation, or mixture of previous texts. In the case of this study, that is to show, how a twentieth-century literary work like Rhys's Wide Sargasso Sea can be related to and a parody of Brontë's nineteenth-century novel Jane Eyre. Moreover, such a postmodern perspective widens various ways of concentration on the literary works; so that, one could interpret in what ways two texts are united and grafted which results in either parody or pastiche. Hypertextuality is the first concept in this study that needs to be defined. According to Genette it involves "any relationship uniting a text $\mathrm{B}$ (the hypertext) to an earlier text $\mathrm{A}$ (the hypotext), upon which it is grafted in a manner that is not that of commentary" (Ctd. in Allen 107-08). Allen mentions that "hypertextuality marks a field of literary works the generic essence of which lies in their relation to previous works" (108). As Genette notes, "Hypertextuality, as a category of works, is in itself a generic or, more precisely, transgeneric architext: I mean a category of texts which wholly encompasses certain canonical (though minor) genres such as pastiche, parody, travesty, and which also touches upon other genres - probably all genres" (Ctd. in Allen 108). This study only focuses on parody. Parody, as Abrams explains, "imitates the serious manner and characteristic features of a particular literary work, or the distinctive style of a particular author, or the typical stylistic and other features of a literary genre, and applies the imitation to a lowly or comically inappropriate subject" (18). The only parodic part of Wide Sargasso Sea is the character of Rochester Jean Rhys creates based on the character of Rochester in Jane Eyre. According to Abjadian Byronic hero "is rebelling against conventional and 'cant political, religious, and moral' values. Byronic hero defies fate and provides the most notable expression of 'World Grief'... [He] wrestles desperately with a cruel world of men, but he is torn more deeply by an unknown taint that hurts and makes him struggle between sin and remorse" (243). However, a parody of such a hero proves to be otherwise, a parodic hero.

Hypertextuality also means any relationship between text A and text B. Wide Sargasso Sea as text B is also related to Jane Eyre, text A, considering the concept of Bildungsroman and the dream works. Abrams also elaborates that Bildungsroman or 'novel of education' is a novel whose subject is "the development of the protagonist's mind and character, in the passage from childhood through varied experiences into maturity and the recognition of his or her identity and role in the world" (132). It deals with the formative years of the main character whose moral and psychological development is depicted.

\subsection{Generic study of Jane Eyre and Wide Sargasso Sea}

Study of the developing stages of the heroines' (Jane and Antoinette's) lives shows the obvious differences in their process of mental development that also makes generic difference between the two novels under study. These differences make Jane Eyre a Bildungsroman whose main character, Jane, becomes an autonomous and mature character, and Wide Sargasso Sea an anti-Bildungsroman whose heroine, Antoinette, reaches madness and destruction. Both characters, Jane and Antoinette, long for independence and freedom. Antoinette often shows her longing to solitude at the height of her problems; therefore, she, in the end, is lonely, locked in the attic and can only reach freedom through death. On the other hand, Jane is interested in improving her condition by fighting against those who tries to oppress her. Jane desires freedom as a young girl and finally gains it, whereas Antoinette passively endures oppression.

\subsubsection{Jane Eyre: A Bildungsroman}

Jane Eyre is an autobiography that starts from Jane's childhood, in a chronological structure in which one phase of her life follows the other. Jane's childhood cannot be considered simply as the prelude to the adult life, King states that, "We live in a society which assumes the importance of childhood as the stage of development in the personality of the adults is largely determined" (7). In this sense, such an idea leads to the Romantic thought of considering 
children as 'miniature adults'. King points to Wordsworth's 'The Child is father of the Man' as the most familiar statement of the concept. This serious attention to the child forms a kind of "fiction known as the Bildungsroman... Translated as 'educational novel', this term refers to novels tracing the development of the central character from childhood to maturity" (7). As childhood has a significant formative role in a character's life; more attention must be on Jane's childhood and then on her adolescence. Her childhood and adolescence are directly related to the years in Gateshead and Lowood; the years of being emotionally suppressed. Therefore, as King concludes, Jane's "development involves a compromise between conflicting elements in herself, the opposing demands of passion and reason" (28).

"Jane's development is a process of learning to say, 'I am', to assert her own identity on her own terms. It is also a process of learning to define those around her in such a way as to understand and thus control the threat they represent to her sense of self" (King 82). In the beginning of Jane Eyre, Jane struggles against Bessie, the nurse at Gateshead. She says, "I resisted all the way: a new thing for me, and a circumstance which greatly strengthened the bad opinion Bessie and Miss Abbot were disposed to entertain of me" (Jane Eyre 7). This sentence foreshadows what will be an important theme of the rest of the book, that of female rebelliousness to gain independence. Jane Eyre shows "Jane's linear progression, a progression", according to Nestor, "toward the acquisition of a wholly unified, rational and conscious identity" (75). In the process of her life, Jane encounters such experiences that build her individuality and teach her to be independent.

In any case, Jane refuses to submit to those in figures of authority, according to King "whether it be the authority of age (Mrs. Reed), social position (Rochester), religion (Brocklehurst and Rivers), or sex (Rochester again). Linked with this characteristic is her outspokenness, and her sense of equality with every one she meets" (45). Jane fights with those who ignore her individuality, trying to make her submissive. This time, in planning their marriage, Rochester dismisses the need to buy jewelry and clothing. It is due to his emotional, moral, and spiritual changing that they can marry a marriage of equals. The final chapter of the novel opens with "Reader I married him" (Jane Eyre 397), and many sentences start, as King states, "with 'I', with Jane as subject... The only other agent is 'he', Rochester, the frequent 'we' asserting his identity and equality with 'I' Jane... Every statement expresses confidence, a sense of control of both herself and her situation" (51). That is to say, each stage of Jane's life follows one another to bring up a passionate, rebellious, dependent child to calm, independent, and content mature woman. Gilbert and Gubar see the novel as 'Jane's pilgrim's progress' towards maturity and selfhood. They consider the novel as

A story of enclosure and escape, a distinctively female Bildungsroman in which the problems encountered by the protagonist as she struggles from the imprisonment of her childhood toward an almost unthinkable goal of mature freedom are symptomatic of difficulties every woman in a patriarchal society must meet and overcome: oppression (at Gateshead), starvation (at Lowood), madness (at Thornfield), and coldness (at Marsh End). (Ctd. in Nestor 74)

Gilbert and Gubar suggest that, Jane's improvement from an orphan child towards a mature woman offers her a personal identity as well. According to Tanner, "...in the end Jane achieves true selfhood, living not as some false self or distorted role that other people try to impose on her, but...with her own self-created, self-defined identity" (Ctd. in Nestor 84). Earlier Jane and Rochester wish to be equal. Finally, Jane is even superior to Rochester both economically and spiritually. This equality, as Showalter thinks, "is not only because Rochester, in losing his hand and his sight, has learned how it feels to be helpless and how to accept help, but also because Jane, in destroying the dark passion of her own psyche, has become truly her 'own mistress"' (75). As a matter of fact, Jane Eyre is traditionally considered to be a Bildungsroman in which Jane grows into selfhood and reaches her desired identity through her demand for equality, an identity that gives her the feeling of security, strength, and autonomy. Jane, as Beaty states, is an adventurous girl who likes to experience 'when she chooses to leave Lowood'; she is passionate and self-esteemed at Thornfield, 'where she falls in love, is loved and betrayed'; she refuses to sacrifice herself even to God's work in the East and returns to 'the man she loved and loves' (215).

\subsubsection{Wide Sargasso Sea: An Anti-Bildungsroman}

Like Jane, Antoinette, the heroine of Wide Sargasso Sea, is shown to pass through phases of childhood towards adulthood in her life; however, her psychic development is quite different. Wide Sargasso Sea, an antiBildungsroman, demonstrates the aspects of Antoinette's life that lead her to loss of self and sanity. Wide Sargasso Sea is the story of a culturally mixed woman, Antoinette, struggling to create a coherent life in a black and white society both of which reject her. She is a Creole woman, white in appearance but black in blood; however, neither the white nor the black accept her. 
Wide Sargasso Sea is the story of Antoinette's growing up from her childhood to her adulthood in the black and white society. Ramchand explains that, "Wide Sargasso Sea is in part about the contrast of two worlds, a contrast which becomes as well 'a lament for the divided self" (11). It is, to a certain extent, the story of isolation, dependence, and loss, physically as well as spiritually. What is evident is that Antoinette, throughout the novel, struggles to gain voice to prove her existence. Howells declares that, "Rhys shows her heroine trying to construct an identity in radically unstable situations where traditions and social conventions prescribe certain rituals but are emptied of meaning" (6).

Antoinette is uncertain about her identity because she is black and white simultaneously, she has a white appearance with black blood; however, her white appearance is rejected by the black and her black blood by the white. It is evident in the opening lines of the novel; Antoinette says, "They say when trouble comes close ranks, and so the white people did. But we were not in their ranks" (Wide Sargasso Sea 15). O'Connor mentions that, "One might believe from this opening that the narrator is, in fact, not white" (171). Antoinette in a child's voice tells that she and her family are poor, alone, and mocked. She explains the condition of the oppressed and despised personality, rejected by all and belonging nowhere. As Childs notes, "The opening suggests that Antoinette does not consider herself important to her own story. The worst aspect to her life for Antoinette is that she does not belong anywhere" (147). Wide Sargasso Sea is the novel, as Howells states, "in which the gaps between whites, blacks, and coloreds are as unbridgeable as those between white Creoles and the English" (109).

The Jamaican blacks never accept white Creoles among their racial group and the English whites as well; they regard them inferior by calling them 'white nigger'. Antoinette's life indicates her development from a young solitary girl in Jamaica to a love-deprived lunatic in an English attic. It is the story of the mental and emotional decline of a human being which is resulted from the heroine's inability to belong to either black or white community. As Luengo points out, Antoinette has internalized the sense of marginalization and oppression. She is told by servants like Godfrey that she and her race are doomed to hell; and later, she herself comes to believe this, "dreaming of damnation at the convent" (174). Wide Sargasso Sea shows Antoinette as inhumanly abused in her family as well as her society and shows her search for love. In addition, O'Connor observes that, "Wide Sargasso Sea recounts and portrays the causes of its heroine's downfall and the sources of her madness... [It] examines the historical, cultural, and social context of isolation" (143).

As a result, Rhys's heroine cannot distinguish between good and evil, her 'struggle is useless' because there is no justice. "Jamaica is a lost Eden whose false perfection was based on social injustice to begin with, and England is a cold 'cardboard house' where Bertha walk at night" (Lindroth 89). Wide Sargasso Sea defines the heroine's separation from her land and reveals her alienation in an oppressive country, England, far from Jamaica; a separation as wide as Sargasso Sea, that leads to her lack of self and sanity as well as lack of identity. Passing the Sargasso Sea physically, Antoinette completely loses her identity and stability.

\subsection{Analysis of Dream Texts in Jane Eyre and Wide Sargasso Sea}

The interpretation of the dreams of Jane and Antoinette reveals the effects of these dreams on the lives of these characters that reflect their suppressed lives and selves in Brontë's Jane Eyre and in Jean Rhys' Wide Sargasso Sea. According to Sigmund Freud, dream work is "the process by which real events or desires are transformed into dream images" (Ctd. in Barry 98). In these two novels, both Jane and Antoinette, experience some visionary dreams that reflect their lost identities. Dreams usually convey meanings in a symbolic form represented by some images. Freud believes that, "a dream is an escape-hatch or safety-valve through which repressed desires, fears, or memories seek an outlet into the conscious mind" (Ctd. in Barry 99). Repressed emotions, fears, and wishes that are forbidden in the conscious mind usually enter the dream world. The dream, in fact, reveals the emotions of the dreamer that he or she attempts to mask in order to be an ideal and accepted person in the society.

\subsubsection{Jane's Dreams}

Throughout her life, Jane has dreams most of which present images of infants. Bessie, the maid in Gateshead thinks that, "to dream of children was a sure sign of trouble either to one's self or to one's kin" (Jane Eyre 193). Jane believes Bessie's superstitious belief about a child in a dream until the night at Thornfield when she dreams of an infant for some successive nights. These dreams foreshadow the later troubles in Jane's life, after each dream she encounters troubles such as Mr. Mason's reaction to Bertha's attack, or the news about John Reed's suicide and Mrs. Reed's lying in deathbed. Jane's dreams, according to Heilman, "are symbolic representations through which the author plumbs the heroine's psyche, rather than simply thrilling additions to the drama" (Ctd. in King 40). particularly, the dreams of children are not just the sign of some trouble or bad omen, they go back to dreamer's 
International Journal of Applied Linguistics \& English Literature

ISSN 2200-3592 (Print), ISSN 2200-3452 (Online)

Vol. 1 No. 6; November 2012

psychological problems and are the symbol of her repressed emotions. Jane's dreams reveal her suppressed passionate unconscious self.

Initially, in Jane's dreams, as Homans states, 'the dream self is Jane, and the child and the trouble it portends are quite external to her'. For example, in the case of Mr. Mason's outcry 'Jane is clearly distinct from the child and the trouble external to her'. Also, in the case of the news about Mrs. Reed, 'Jane now becomes the child and the other in someone else's subjective experience'. That is, 'these dreams question and break down the boundary between subject and object, between self and other' (152-53). Therefore, Jane's dreams can be considered as a struggle between her self as a subject and the other as an object, and in other words, her single and married selves.

In the days after her engagement to Rochester, she has a feeling of estrangement considering herself as Jane Rochester. Evidently, Jane dreams her married self as a new born child whose presence is not certain to Jane and she fears that in changing her name from Eyre to Rochester she will lose her autonomy and independence. Jane is not content of becoming Mrs. Rochester, or she fears to be Jane Rochester because she thinks it will take her freedom. She knows that in the case of her marriage to Rochester, like other women of her society, she should be submissive to her husband in order to be an ideal lady. As a result, this feeling shows itself in her dreams and she sees the supposed Mrs. Rochester in the form of an infant who 'shivers' and 'clings round her neck'.

In Jane's two important and successive dreams the child is the true vision of Mrs. Rochester as an unborn child, a child who is feeble, shivering and wailing. Homans argues that, "In these dreams, Jane is the surrogate mother of a child she seems not to know, but that they almost directly follow an image of birth suggests that the child does belong to the dreamer, who is unwilling to acknowledge" (154). Jane is not ready to be Mrs. Rochester and sees the supposed Mrs. Rochester as a barrier between her and Rochester. The second dream seems to be the continuation of the first one, but she dreams herself in Thornfield Hall. According to Bessie's prophecy, the dreams of children bring trouble. Jane wakes up from her second dream to discover Bertha tearing her wedding veil. The problem that follows this dream, as Poovy states, "is Mason's denunciation in the church, Rochester's revelation that he is already married, and obliteration of Jane's hopes to formalize her kinship with Rochester" (183). Consequently, the second dream is the prediction of some events, such as the destruction of Thornfield Hall and also Jane and Rochester's separation foretold as he is riding away from Jane in the dream.

The first two dreams reflect a fear that Jane hides from herself and others, that marrying Rochester will change her identity. In the first dream, Jane herself is in an unknown road that signifies her fears of future life as Rochester's wife. As she does not have Rochester's experience of the world, the future life is unknown for her. The child of the dreams is representative of Mrs. Rochester, a new identity for Jane, and a representative of Jane as an orphan child. Jane is preoccupied by it until she reaches maturity, independence and also equality with Rochester because it is the cause of her inequality with Rochester and his rank. Therefore, the dreams make Jane feel like an unwanted person if she becomes Mrs. Rochester. However, two nights later when Jane decides to leave Rochester she experiences the third dream in which Jane herself is the child and the mother is a spirit, a visionary mother.

The third dream is set in the scene of the red room. But instead of terrifying ghost of the Gateshead red room, a shining glorious human form comes down and comforts Jane. The dream prefigures Jane's flee from Thornfield Hall and her wander in nature. Jane calls the landscape her mother but this mother is a figurative one and cannot protect her from the dangers of the outside world. In the third dream, as Homans demonstrates, "The self has become a child, yet the wedding has failed to take place, and the dream child now is manifestly not Mrs. Rochester. Unable and unwilling to give birth to that troublesome child, Jane regresses to a version of her own childhood" (155). Being a child who is loved by a mother is the opposite of the previous dreams in which the dream child is not loved by a mother figure and is considered as a burdensome child. The mother figure in the third dream, persuading Jane to flee, deceives her because Jane in outside is defenseless and the Mother Nature unlike her soothing voice in the dream cannot help her in reality. In the third dream, the ghost of Jane's dream can be part of her unconscious that enables her to resist Rochester.

Jane thinks about nature as her spiritual mother and that she can feel secure with her but, on the contrary, with Mother Nature Jane comes nearly to death because in this case matriarchy is powerless. Thus, Jane's relation as a child with Mother Nature becomes instable because as Boumelha specifies Mother Nature cannot fulfill essential needs of Jane the daughter and this reveals the powerlessness of matriarchal world in front of powerful dominant patriarchal society, evident in the acceptance and survival of Jane by a male figure St. John Rivers and not female figures of the society (136). As a result, the mother figures in Jane's dreams are unstable and unsafe refuge for the burdensome child. 
Poovy sees the appearances of children in Jane's dreams as the dependent figures that show women's dependent position in the patriarchal society. It also shows governess' dependent position along with the rage that her dependence to the male figures provokes (184). Throughout the novel, Jane tries to reach independence against the conventions dominant in the society; however, she endures many difficulties to gain it in patriarchal society; therefore, this suppressed self show itself in her dreams of children. The married woman finds it difficult to preserve her independence and autonomy in the society dominated by patriarchy. She is forced to her husband's name and to submit herself to his will entirely. Jane will become suppressed and will lose her self-respect and independence if she depends on Rochester. Although, in the end, Jane bears Rochester a son, in her dreams, Jane unconsciously rejects the role of being mother. In the dream before her wedding Jane dreams herself 'burdened with the charge of a little child' (Jane Eyre 248). In the next dream, she is also burdened with the small child, in which "an unconscious negativity towards motherhood is evident" (Nestor 50). This sense of not being prepared to be a mother indicates Jane's inequality with Rochester and makes her feel unready to start a marital life. Although she loves Rochester and looks forward to marrying him, this sense of inequality shows that unconsciously she is not ready to marry and her reluctance is shown in her dreams as a burdensome child and a reluctant mother. The main factor of her rage is the male oppression of identity. The ideal women of a patriarchal society were not supposed to show anger; consequently, the suppressed anger appears in her dreams. Jane's inferiority feeling causes her to be separated from Rochester both in dream and in reality.

\subsubsection{Antoinette's Dreams}

Antoinette's dreams also have close relationship with her life and self-identity like those of Jane's. Jean Rhys built her character, Antoinette, around the framework of the three ominous dreams. Her three dreams are dreams that foreshadow the future events of her life; each dream is the continuation of the previous one and gives insight to Antoinette's descent in her life. According to Maurel, "This threefold nightmare partakes of the prophetic dimension of Wide Sargasso Sea" (140). Each dream somehow prophesies some major events of Antoinette's future life. Her dreams are, to a certain extent, the abbreviated version of her life. Antoinette's dreams reveal her repressed self. In her dreams, Antoinette is shown as a suppressed and submissive character in the patriarchal society; she also suffers a disintegration of selfhood. In fact, "through her dreams, Antoinette continues her exploitation of the otherness eclipsed by European rationality" (Emery 48).

Antoinette, first, experiences her nightmarish dream as a child, on the evening of the day she had a quarrel with Tia, The significant aspect of this dream is that Antoinette confronts hatred. Someone with 'heavy footsteps' is following her whose sex is not clear. She also cannot move which depicts her immobility. The whole dream represents loneliness, fear, and hatred that Antoinette experiences in her life. Her struggle to move; on the other hand, reveals her attempt to free herself from an undesirable situation. According to Gregg, "The dream in its first appearance hints at the danger which awaits the protagonist, as she is in a forest being followed-by-someone who hates her" (162).

Thomas comments on Antoinette's first dream and points out that it is caused by a 'mocking little girl', 'Tia's verbal attack', laughter of English gentleman, and 'her mother's passive aggressive refusal to speak to or look at her' after her appearance in dirty dress (184). Antoinette first dreams as a child, the night after Tia cheats her, steals her dress, and dismisses her as a 'white nigger'; Tia's verbal attack and disregard and the English visitors' mocking laughter cause Antoinette's dream that reflects her undeveloped self.

The heavy footsteps may imply the male steps that frighten her, representing bad effect, and forecast the oppressing footsteps Rochester will have in her future life. The dream, somehow, predicts Antoinette's future fears in life. Antoinette has her bad dream for the second time at age of seventeen, in the convent, after her stepfather's visit and as Harrison states, when "she is fearful of what it may mean to be outside the world of the caretaking sisters and the company of the other girls, with 'strangers' - not only men" (167). Unlike the first dream in which Antoinette is walking in the forest followed by the mysterious figure who hates her, in the second one she is following the man whose face is 'black with hatred'. The man's face prefigures Rochester's disgust and lack of love towards Antoinette. In addition, her dress is 'long' that hinders her walk and is 'white and beautiful' that can be the symbol of a bridal gown.

The dream, in fact, suggests Antoinette's adolescent sexuality and her anxiety about her arranged marriage. It also suggests the troubles that Antoinette will face after meeting Rochester. In this dream, as Spivak states, "Antoinette finds not love, but a strange, threatening voice inviting her into a prison which masquerades as a love. The sexual imagery is conveyed through the reference to the beautiful white dress and thin slippers, symbols of virginity about to be deflowered and white reinforces the theme of death" (Ctd. in Gregg 162). Moreover, she follows the man with fear and without any attempt to save herself that conveys her passivity and her disinclination to change her fate and 
inevitability of what must happen. The second dream evidently foreshadows her fall. Her departure from Coulibri and finding herself in an unknown and different garden foreshadows her departure from Jamaica and going to England. The 'enclosed garden' with different trees might be Thornfield Hall having 'steps leading upwards' that leads to Antoinette's attic prison. The unfamiliar trees with no way to escape, as Le Gallez explains, "must imply that the location has altered to a totally different geographical region in which the flora is of a species which is new to her" (164).

In each dream, Thomas notes, "Antoinette is being stalked: in the first by the 'heavy footsteps' of a hater, who avoids her gaze; in the second, a nuptial dream, by a man whose face is 'black' with hatred; in the third by the rumored ghost of Thornfield Hall, Bertha Mason" (183), which implies her fearful confused life, a threat to the white Creole woman's subjectivity. By the time she has the third dream, Antoinette has transformed into Bertha locked in the attic of Thornfield. She has lost the ability to distinguish between dream and reality. Antoinette has escaped into madness to free herself from imposed identity. Emery, focusing on Antoinette's third dream, states that, "Through the third and final dream, the novel exceeds and overturns the limitations of its predetermined ending" (56). It is in this dream that Antoinette searches for a way of action and her dream will tell her what she must do. Le Gallez refers to Antoinette's attraction towards fire, and suggests that "any course of action which she chooses is likely to be quite explosive" (166).

The last dream is more significant because it relates Rhys's text to Brontë's. The last dream foreshadows her final act of destroying Thornfield Hall. After this dream she realizes her situation and reviews her past life. She says, "Now at last I know why I was brought here and what I have to do" (Wide Sargasso Sea 155). Harrison points to Antoinette's third dream as "The dream that is used as general metaphor for context in Antoinette's early exchange with Rochester and as the structural recapitulation of Brontë's censored dream-text takes on its full power as the book comes to its conclusion and Antoinette's 'dream' in the last section becomes reality" (169). Antoinette's final dream takes her back to those days of the past, days in Coulibri, in convent and in Aunt Cora's house; Antoinette shifts her description between Thotnfield and Coulibri, now she does not walk but floats, and as Emery states, "If Antoinette has walked like a living dead, she has now awakened to fly, fulfilling the traditional slave for wings with which to fly home" (57). In this dream like the first one, Antoinette is followed by someone, by a ghost that is said has haunted the house. She is in a room in Thornfield Hall in which the softness of couch annoys her and makes her anxious because "Antoinette is not used to such comfort in the separation conditions of the attic rooms where she is confined" and also "Possibly her desire to 'get out of the room' reflects a desire to be free of all the restrictions imposed on her by [Rochester]" (Le Gallez 169).

The third dream also leads to the end of dreams and to the end of the text. It illustrates how Antoinette's identity is completely diminished through patriarchal oppression that when she looks in the mirror she does not recognize her own reflection, "It was then that I saw her - the ghost. The woman with streaming hair. She was surrounded by a gilt of frame that I knew her" (Wide Sargasso Sea 154). Antoinette does not realize that what she sees is a reflection of her selfhood; because as her name has transformed into Bertha, her selfhood also has been spoiled and divided into two parts. In fact, Antoinette is an individual who has been changed into other by patriarchal oppression. By gazing in the flames Antoinette flashes back to her past life seeing her grandfather, Aunt Cora's patchwork, orchids, jasmine and her doll's house. She hears Coco's call and the man calling 'Bertha'. Antoinette's inability to recognize her voice as she screams reflects her loss of self-recognition. According to Gregg when Antoinette calls Tia by name and jumps, she joins her lost identity, her self. The break is removed and the scar of Tia's stone on Antoinette's face as well as on her life will be removed (164). When Antoinette decides to jump into the pool to join Tia, she is deciding who she is. By escaping 'the man who hates me' and his cries for 'Bertha', Antoinette refuses to be Bertha. This escape is not possible but through her death. Finally, Antoinette regains her identity when she figuratively jumps from the battlements of burning Thornfield Hall.

It may be concluded that Jane and Antoinette's dreams, in Jane Eyre and Wide Sargasso Sea, reveal their mental states. Jane's dreams reflect her repressed self and the soul mate she desires to have and Antoinette's dreams reflect her search for lost self. In these dreams, both Jane and Antoinette seek for someone and as Harrison notes, "The 'someone' of [Antoinette's] first dream - identified with Rochester - has become herself, a woman, the one that she seeks; unlike Jane Eyre, who, in her dreams, seeks Rochester" (172).

\subsection{Analysis of the Character of Rochester in Jane Eyre and Wide Sargasso Sea}

The analysis of the character of Edward Rochester indicates how Rochester in Jane Eyre shows Byronic traits and Rochester in Wide Sargasso Sea anti-Byronic traits. The main male character's name in Jane Eyre is Mr. Rochester who has a very mysterious history while the man in Wide Sargasso Sea moves to the Caribbean after 
living in England for his entire life. Jean Rhys never states that the two men are the same, but the similarities between the two led the reader to believe it is so. Rochester in Jane Eyre is a gallant, decisive, unconventional, and rebellious man, a Byronic hero; whereas, Rochester in Wide Sargasso Sea is a cruel, indecisive, disloyal, and conventional man, an anti-Byronic hero.

\subsubsection{Rochester as Byronic Hero in Jane Eyre}

Charlotte Brontë uses her character Edward Rochester to portray the prototype of the Byronic hero. Rochester is presented as extremely masculine with an emphasis on his power and energy in Jane Eyre. King refers to Rochester as "a shade of Byronic gloom and appetizing mystery", and sees the conception of the Byronic hero as "a rebel, dark and compelling in appearance, though not handsome: a man who exercises considerable charm over women in spite of a guilty secret from which he is trying to escape" (41). Consequently, he is an unhappy and isolated man who despises his fate.

Rochester has a sinful past and admits his errors but blames his father as being responsible for his miseries. As King mentions, "He describes his wanderings in exile after his marriage, using his unhappiness as justification for 'overleaping an obstacle of custom' which his own judgment does not accept as an impediment" (42). Rochester is a dark and mysterious stranger who rebels against conventional morality and resists fate. "He sees himself as 'burdened' with a 'curse' and opposes his 'rational' justification to divine law" (King 42). Significantly, he does not take into consideration the law dominant in the society, especially the marriage law; hiding his mad wife, Bertha, from everyone, he tries to marry Jane. He prefers self-interest actions for his own satisfaction and pays little attention to what people would think or say about him. When his secret of having another wife is discovered, he insists Jane to be his mistress and to live with him forever without paying attention to the marriage law and morality dominant in the society. For him his happiness is prior to the conventions; in fact, he has a power to make " unheard of rules" (Weiser 65), to make Jane his mistress and to keep her for himself for ever. As a result, his individual desires are more important than the laws of society. Shuttleworth mentions that, "[Rochester] denies, initially, the physical existence of the woman who tore her [Jane's] veil, thrusting on Jane, rather, the label of hysteric with his suggestion that it was 'the creature of an over stimulated brain"' (171).

Therefore, hiding his secret, he uses his male power to dominate Jane suggesting that she had been dreaming. A typical masterful and passionate Byronic hero attracts women and dominates their love. Furthermore, Rochester justifies his behavior with Bertha and shows himself as the victim of his father's plans. He talks about Bertha as a beast and denies her humanity. Being locked to a lunatic wife, Rochester feels right to do whatever he likes. He, as Stoneman states, "has freedom of action and movement; he is decisive and authoritative; he has wealth and independence; he has experience of multiple relationships, and retains the right to autonomous action such as his attempt at bigamous marriage" (89). The most significant of all he is an unconventional man whose actions are against dominant rules of society.

Furthermore, apart from his financial strength, he is also physically strong man especially in comparison to little, pale, and fragile Jane which shows his superiority over Jane and others as a master. In truth, Rochester is a masterful person and enjoys it. He commands Jane's presence in his room and in the other occasion in front of his guests. Later he tries to dominate her by buying her expensive clothing. Even Rochester's first appearance is unusual, Jane resting on a stile in her walking out hears a horse approaching: "As this horse approached...I remembered certain of Bessie's tales wherein figured a North-of England spirit, called a 'Gytrash'; which, in the form of a horse, mule, or large dog, haunted solitary ways, and sometimes come upon belated travelers, as this horse was now coming upon me" (Jane Eyre 97). The horse slips and its rider falls; Jane helps him and later learns that he is Mr. Rochester, the master of Thornfield Hall. This sudden and unexpected appearance is surely the characteristic of Byronic hero: restless, mysterious, and unforeseen. On the other hand, Mrs. Fairfax admits that Mr. Rochester after owning his property in his brother's death has been unable or unwilling to stay at Thornfield more than two weeks at a time, which is the actual personality of Byronic hero, being restless and uncomfortable. Moreover, in order to escape his past; Rochester, from time to time, abandons Thornfield Hall and disappears for months. Actually, he is trying to escape reality that hurts him.

Byronic hero also has a sinful past life; he is portrayed as a womanizer who has illegal relations with infamous women in society. Rochester also has such experiences in his past. He talks to Jane about Céline Varnes, a French actress, and his betrayal by her. In fact, as Beaty suggests he is 'victimized by his French mistress' and he leads a 'life of dissipation' (69). Rochester's conversations are completely unconventional to such an extent that surprises Jane. His confessions about his past exemplify his shocking frankness with Jane. It is after Céline's disloyalty that Rochester starts an immoral life. Rochester always keeps Jane in fear of his feeling toward Jane and Jane is always in 
International Journal of Applied Linguistics \& English Literature

ISSN 2200-3592 (Print), ISSN 2200-3452 (Online)

Vol. 1 No. 6; November 2012

aspiration of Rochester's affection. Jane continually dreads whether Rochester will seek her company or not. One day Rochester admires Jane's paintings, the other day dismisses her abruptly as if he is tired of her. Rochester, in Jane's eyes, is an ambiguous character and as Beaty notes, "His actions and words do little to clarify his moral character. His brusque manner is not entirely charming and he is masterful to the point of being rude" (91).

Weisser explains Rochester's character as "moody, hard to 'read', an intensely private and convoluted hero who presents no surface smoothness or conventional blandness on which to depend: he constitutes a secret" (62). He also likes to keep his full power of masculine sexuality, and likes to use this power to control everyone, especially Jane. In the gypsy scene, as Shuttleworth points out, "he offers to analyze [Jane's] destiny from her face and forehead. Disguised as a woman, Rochester enjoys free access to Jane's unprotected interiority" (71). Explicitly, Rochester attempts to penetrate in and control Jane's psyche. Rochester, in his efforts to force Jane to reveal her inner self especially her feelings toward him, becomes cruel and causes Jane great pain, like his lies about his marriage to Blanche to see her reaction and to force her admission of her feelings for him. In this way, he has full control over their relationship.

\subsubsection{Rochester as Anti-Byronic Hero in Wide Sargasso Sea}

The characteristics of Edward Rochester in Wide Sargasso Sea demonstrate him as an anti-Byronic hero. Jean Rhys in a letter introduces Rochester as "a fierce and violent man who marries an alien creature... My Rochester as I see him becomes... as jealous as Othello... I have tried to show this man being magiced by the place which is a lovely, lost, and magic place but, if you understand, a violent place" (Ctd. in Stoneman 181). Rochester, being the younger son of a wealthy father, is deprived of his certain rights in favor of his elder brother. Therefore, penniless and powerless Rochester has to yield to the arranged marriage with a rich heiress without love. As Maurel mentions, "Rochester finds himself thrust into an alien culture for financial reasons" (134). In fact, in the course of the novel, Rochester's cruelty toward Antoinette is due to a projection onto her of his hate for his father and for the arranged marriage. He says, "They bought me, me with your paltry money. You helped them do it. You deceived me, betrayed me" (Wide Sargasso Sea 139). His anger is the anger of an oppressed. Rochester is a weak and an unstable person. Thorpe notes that, "his inferior position in his family, his exile from what is familiar, the fever he is plunged into on his arrival in Jamaica, these all leave him groping for some sure ground for self; he is skeptical of life's promises and... of happiness" (183). Like Antoinette, Rochester is a vulnerable person both in his family and society, but he conceals it. Ramchand mentions that, "we are able to contrast the feelings and attitudes he keeps to himself with the behavior his tight suppression permits him to show" (202). In the second part of the novel, from the very beginning of Rochester's narrative one can observe Rochester's "antagonism toward the island and his new wife in metaphors of military conquest" (Emery 48). He says, "So it was all over, the advance and retreat, the doubts and hesitations. Everything finished, for better or for worse" (Wide Sargasso Sea 55).

Rochester is a hypocrite and dishonest man, he presents his marriage to Antoinette that "was all very brightly colored, very strange, but it meant nothing to me. Nor did she, the girl I was to marry... I played the part I was expected to play... I must have given a faultless performance" (64). In reality, Rochester marries Antoinette just for her money without paying attention to her beauty. He says, "I wondered why I had never realized how beautiful she was" (67). Rochester uses Antoinette's beauty just for his masculine pleasure. He looks at her in the same way as he looks at her island. The island is different from England, it is too colorful; as well Antoinette's beauty is different from English beauty, she is too beautiful. There is always lack of understanding in the couple's discussions that suggests "Rochester's implicit and habitual dishonesty waiting for an opportunity to gain mastery" (O'Connor 150).

Rochester, distinct from Byronic hero who is a wanderer and likes to live outside the established norms of the society and likes the solitude, prefers social institutes. He fears wild, mysterious, and thick-with-tree places around Granbois. According to O'Connor, "Rochester's initial response to the scenery he sees on the horseback ride to Granbois reveals his antipathy to this new land... The fear of suffocation may well be connected to the fear of annihilation...by the powers of the opposite sex which are for Rochester both seductive and repellent... The island represents Antoinette's powers" (148). In point of fact, Rochester's ride to Granbois following Antoinette represents his dependence and insecurity. Everything new and unfamiliar is frightening Rochester. What he hears is silence and what he sees is nothing and the trees were his enemy. Everything seems menacing to him as he is far from his country. Everything is unknown and mysterious; his wife is 'a stranger' for him. Rochester always talks about Antoinette with hatred; he turns his antagonism for his father against Antoinette.

An anti-Byronic hero seems to be a conventional man, obedient to norms and standards dominant in the society because he has no power and courage to oppose authority. Rochester cannot do anything against his father's will and cannot oppose to the marriage arranged by him. He has no control over his life, others decide for him and he obeys 
with no protest. This makes him a timid man; actually, he is worried to be disapproved by others. Rochester cannot stand Antoinette's rejection and tries to persuade her to marry him in any possible way. He says, "I did not relish going back to England in the role of rejected suitor jilted by this Creole girl" (Wide Sargasso Sea 65). As O'Connor points out, "he fears that those who serve and administer to the native whites mock him and despise him, watching him with unfriendly and suspicious eyes" (149).

The most significant element that makes Rochester an anti-Byronic hero is lack of identity. Throughout the novel he is not called by name and the reader knows him as Antoinette's husband, as the younger son, and as the stranger to that island. He is referred as 'man' or 'husband' and never Edward Rochester. He is a nameless hero in the process of the novel, according to Harrison, "Neither Rhys nor Grace Poole (nor even Mrs. Elf) names the man, and Grace Poole places him in relation to an equally unspecified father and brother. Early in his own narrative he identifies himself as 'a younger son'... If Rochester has any identification by name here, it is as Antoinette's husband or at least as the man whose 'wife' is Antoinette" (201-2). The lack of name leads to lack of self-confidence.

Moreover, Rochester's materialistic personality gives him the power and authority to control everyone in the same way his father did. By possessing Antoinette's wealth of thirty thousand pound Rochester tries to gain his authority ignored by his family. Being suppressed from his childhood, Rochester has also adopted a subordinate position after marriage; he follows Antoinette. The feeling of being follower annoys him and he seeks an opportunity to gain his suppressed power. As Le Gallez notes although Antoinette's money brings Rochester 'complete financial independence', and gives him his lacked 'self-respect', he has had to 'forfeit his soul' (146). In one of his letters to his father he says, "I have sold my soul or you have sold it, and after all is it such a bad bargain" (Wide Sargasso Sea 59)?

Consequently, Rochester's character developed by Jean Rhys is exactly in opposite way of that of Charlotte Brontë. Brontë's hero, although is felt as a victim, is a strong man whose bad fortune has brought him to a state of Byronic hero; love for him is sacred and he is ready to sacrifice whatever he has to save his love. On the other hand, Rhys's hero is a petty, coward, disloyal, and dishonest man who projects all his defects on his wife. For him love is nothing and even worse than nothing; he can easily sacrifice love to gain money, power and authority. In Jane Eyre Rochester is less brutally portrayed, but is still forced to recognize the limits of his masculine world. Brontë portrays Rochester as a man with a dark past who nevertheless is not to blame. But Rhys in Wide Sargasso Sea sees this situation from a different angle. She introduces a complex power structure when the same individual enacts domination and resistance, for different purposes. That is due to all these characteristics that he is considered as antiByronic hero.

This paper was an attempt to show that Jane Eyre and Wide Sargasso Sea are hypertextually related; that is to say, the latter is the hypertext of the former. The character of Rochester in Wide Sargasso Sea parodies the character of Rochester in Jane Eyre. Wide Sargasso Sea as a hypertext of Jane Eyre is also related to it through two other aspects, one is generic and concerned with the concept of Bildungsroman including the mental development of the main character; the other is the concept of dream texts which are dominant in both novels.

\section{References}

Abjadian, Amrollah. A Survey of English Literature II. Tehran: Samt, 2002.

Abrams, M. H. A Glossary of Literary Terms. Orlando: Harcourt Brace College Publishers, 1993.

Allen, Graham. Intertextuality. London: Routledge, 2000.

Barry, Peter. The Beginning Theory, An Introduction to Literary and Cultural Theory. Manchester: Manchester University Press, 2002.

Beaty, Jerome. Misreading Jane Eyre: A Postmodernist Paradigm. Columbus: Ohio State University, 1996.

Boumelha, Penny. "Jane Eyre", Jane Eyre. ed. Heather Glen. London: Macmillan Press Ltd., 1997.

Brontë, Charlotte. Jane Eyre. London: Wordsworth Classics, 1999.

Emery, Mary Lou. Jean Rhys at "World's End": Novels of Colonial and Sexual Exile. Austin: University of Texas Press, 1968.

Gregg, Veronica M. "Symbolic Imagery and Mirroring Techniques in Wide Sargasso Sea", Critical Perspectives on Jean Rhys. ed. Pierrette M. Frickey. Washington: Three Continents Press, 1990. 
International Journal of Applied Linguistics \& English Literature

ISSN 2200-3592 (Print), ISSN 2200-3452 (Online)

Vol. 1 No. 6; November 2012

Harrison, Nancy R. Jean Rhys and the Novel as Woman's Text. Chapel Hill: The University of North Carolina Press, 1988.

Homans, Margaret. "Dreaming of Children: Literalization in Jane Eyre", Jane Eyre. ed. Heather Glen. London: Macmillan Press Ltd., 1997.

Howells, Coral Ann. Jean Rhys. London: Harvester Wheatsheaf, 1991.

King, Jeannette. Jane Eyre. Philadelphia: Open University Press, 1986.

Le Gallez, Paula. The Rhys Woman. London: The Macmillan Press Ltd., 1990.

Lindroth, Colette. "Whispers Outside the Room: The Haunted Fiction of Jean Rhys", Critical Perspectives on Jean Rhys. Ed. Pierrette M. Frickey. Washington: Three Continents Press, 1990.

Luengo, Anthony. "Wide Sargasso Sea and the Gothic Mode", Critical Perspectives on Jean Rhys. Ed. Pierrette M. Frickey. Washington: Three Continents Press, 1990.

Maurel, Sylvie. Jean Rhys. New York: St. Martin's Press, 1998.

Nestor, Pauline. Charlotte Brontë's Jane Eyre. London: Harvester Wheatsheaf, 1992.

O'Connor, Teresa F. Jean Rhys: the West Indian Novels. New York: New York University Press, 1986.

Poovy, Mary. "Jane Eyre and the Governess in Ninteenth-Century Britain", Approaches to Teaching Brontë's Jane Eyre. ed. Diane Long Hoeveler and Beth Lau. New York: The Modern Language Association of America, 1993.

Poovy, Mary. "The Anathematized Race: The Governess and Jane Eyre", Jane Eyre. ed. Heather Glen. London: Macmillan Press Ltd., 1997.

Ramchand, Kenneth. "Wide Sargasso Sea", Critical Perspectives on Jean Rhys. ed. Pierrette M. Frickey. Washington: Three Continents Press, 1990.

Rhys, Jean. Wide Sargasso Sea. London: Penguin Books, 1968.

Showalter, Ealine. "Charlotte Bronte: Feminine Heroine”, Jane Eyre. ed. Heather Glen. London: Macmillan Press Ltd., 1997.

Shuttleworth, Sally. Charlotte Brontë and Victorian Psychology. Cambridge: Cambridge University Press, 2004.

Stoneman, Patsy. Brontë Transformation: The Cultural Dissemination of Jane Eyre and Wuthering Heights. London: Harvester Wheatsheaf, 1996.

Thomas, Sue. The Worlding of Jean Rhys. Westport: Greenwood Press, 1999.

Thorpe, Michael. "The Other Side: Wide Sargasso Sea and Jane Eyre", Perspectives on Jean Rhys. ed. Pierrette M. Frickey. Washington: Three continents Press, 1990.

Weisser, Susan Ostrov. Women and Sexual Love in the British Novel, 1740 - 1880. London: Macmillan Press Ltd., 1997. 